\title{
Recognition of the Rights of the Victims of Climate Change under Public International Law: A Study
}

\author{
Piyali Sengupta *
}

\begin{abstract}
In recent years, climate change is emerging as a major environmental disaster. The impact of such disasters has been the rise in global temperature and flooding of coastal zone communities, frequent droughts and disruptions in rainfall pattern. This has resulted in the increase in the number of environmental refugees. Climate change disasters constitute a major reason for displacement of population than war and persecution. Climate induced migration is a highly complex issue. The status of climate refugees is not recognized in the international framework. The non recognition of these victims in international and national legislations has not only deprived them of their basic human rights but has also raised crucial questions relating to their existence and identity. This paper tries to bring out the lacunae in the present policy and legal framework relating to environmental refugees with reference to the non-refoulement principle. Further, the paper emphasizes on the need to include climate refugees under the term 'refugee' as laid down in the United Nations Convention relating to the Status of Refugees, 1951and provides suggestions for improving the condition and protection of this hitherto neglected population.
\end{abstract}

* Second Year, BA LLB, Hidayatullah National University, Raipur; piyalisengupta12@gmail.com. 
Keywords: Climate change, Human rights, International framework, Migration, Refugees

\section{Introduction}

Environmental disasters not only lead to loss of livelihoods, cattle, crops etc. But also results in migratory movement of population at large. Environment and human rights are seen as the two noble fields that seldom interact and have different arenas of application. ${ }^{1}$ There has been a complex nexus created between climate change concerns and its impact on human life. It was in 1990 that the Intergovernmental Panel on Climate Change (IPCC) predicted that 'the gravest effects of climate change may be those on human migration as millions are displaced by shoreline erosion, coastal flooding and severe drought'. ${ }^{2}$ It further went on to add that climate change might necessitate consideration of migration and resettlement outside of national boundaries. ${ }^{3}$

Although environmental displacement has existed since the dawn of humanity, the expression 'environmental refugees' emerged in the mid 1980s. Other terms considered in this respect include ecological refugees, climate refugees, environmental migrants, climate evacuees, eco refugees, persons displaced due to natural disasters, environmentally displaced persons etc. ${ }^{4}$ These migrants

1 United Nations Environment Programme, Benefits of Linking the Human Rights and Environmental Agenda: The Example of Human Rights and Climate Change, Nairobi MA available at, http://www.unep.org/ environmentalgovernance/ Portals/8/documents/ BenefitsHumanrights EnvironmentAgenda.pdf (last visited Jun.10, 2013).

2 SABine PerCh-Nielsen, Understanding the EFFeCt Of Climate Change ON HUMAN MigRATION THE CONTRIBUtion OF MATHEMATICAL AND CONCEPTUAL MODELS 1 (Swiss Federal Institute of Technology 2004), available at http://e-collection.library.ethz.ch/eserv/eth:27632/eth-2763201.pdf (last visited Aug. 22, 2013).

${ }^{3} \mathrm{Id}$.

${ }^{4}$ Cournil,C., The Question of Protection of 'Environmental Refugees' from the Standpoint of International Law, available atpapers.ssrn.com/sol3/ papers.cfm?abstract_id=1994357(last visited Jul. 22, 2013). 
not only include persons who cross international borders in search of refuge and those who are internally displaced, but also stateless persons, population affected by natural disasters and those involuntarily resettled as a result of development projects. ${ }^{5}$

\section{Climate Change and Human Migration}

International interest in the linkages between climate change and human rights is a relatively recent phenomenon. It has only been since 2005 that a small number of vulnerable states, indigenous groups, and non-government organizations have begun to take a series of separate yet mutually reinforcing steps to understand, highlight, and leverage those linkages. ${ }^{6}$ The present estimate of refugees because of environmental degradation in their homeland is 25 million or one out of every 225 people worldwide. ${ }^{7}$ IPCC predicted that there will be 150 million environmental refugees by 2050 - equivalent to $1.5 \%$ of 2050 's predicted global population of 10 billion. Various low lying island nations like Kiribati, Tuvalu, Palau and Maldives are facing increased concerns about the very survival of their statehood, due to rising sea levels induced by global warming. 8

The aftermath of climate change is discernible with reference to the protection required for the refugees. Refugees are people who have fled persecution and lack the protection of their own country. Millions of people have been forced to leave their homes because the land on which they live has become uninhabitable or is no

5 Susan Martin, Forced Migration, the Refugee Regime and the Responsibility to Protect, 2GLOBAL RESPONSIBILITIES PROTECT38(Feb., 2010).

${ }^{6}$ Marc Limon, Human Rights and Climate Change: Constructing A Case For Political Action, 33 HARV. ENVTL. L. REV., 439 (2009).

7 INTERNATIONAL ORGANISATION FOR MigRATION, MigRATION Environment And Climate Change: Assessing The Evidence, (Frank Laczko \& Christine Aghazarm eds.,) available athttp:/ / publications.iom.int/ bookstore/free/ migration_and_environment.pdf (last visited Aug. 22, 2013).

${ }^{8}$ Neha Bhat, To Be or Not To Be: The 'Environmental Refugee', available atpapers.ssrn.com/sol3/papers.cfm?abstract_id=2170877 (last visited Aug. 13, 2013). 
longer able to support them. The complex relationship between human mobility and environmental degradation needs to be addressed through the international regulatory framework.

According to Article 1 of the United Nations Convention relating to the Status of Refugees, 1951 (CSR 1951), a refugee is a person who,

Owing to a well founded fear of being persecuted for reasons of race, religion, nationality, membership of a particular social group or political opinion, is outside the country of his nationality and is unable or, owing to such fear, is unwilling to avail himself of the protection of that country; or who, not having a nationality and being outside the country of his former habitual residence as a result of such events, is unable, or owing to such fear, is unwilling to return to it.

The CSR 1951, with its Protocol relating to Status of Refugees adopted in 1967 (Protocol 1967) has amended the definition of 'refugees'. But environmental refugees still do not fit into this definition.

The expression 'environmental or climate refugees' has not been defined; no legal text uses such a term. The IPCC also recognized the effects of climate change on human life as a matter of grave concern. ${ }^{9}$ It was for the first time in the World Conference on Human Rights in Vienna in 1993 that the international community recognized the absence of an international framework for human migration induced by climate change. ${ }^{10}$

The United Nations Environment Programme (UNEP) defined environmental refugees in a manner consistent with the humanitarian mission of their agency rather than using more analytical criteria. UNEP researcher Essam El-Hinnawi in 1985 first defined environmental refugees as,

${ }^{9}$ Climate Change: The IPCC Scientific Assessment (1990) 410 (J.T. Houghton, G.J. Jenkins and J.J. Ephraums eds., Cambridge University Press 2010).

${ }^{10}$ General Assembly, Vienna Declaration and Program for Action, U.N. Doc. A/CONF. 157/23 (July 12, 1993), available at http:/ / www.unhchr.ch/ huridocda/huridoca.nsf/\%28symbol\%29/a.conf.157.23.en. 
"Those people who have been forced to leave their traditional habitat, temporarily or permanently, because of a marked environmental disruption (natural and/or triggered by people) that jeopardized their existence and has seriously affected the quality of their lives. By 'environmental disruption' in this definition is meant any physical, chemical, and/or biological changes in the ecosystem (or resource base) that render it, temporarily or permanently, unsuitable to support human life".11

According to him, there are three main types of environmental refugees:

a. People who are temporarily displaced because of environmental stress. In this case, once the environmental disruption is over and it is safe to return, refugees can return to their habitat. An example of this is the Boxing Day Tsunami of 2004 in the Indian Ocean, which caused in Banda Aceh alone, the displacement of estimate 406,000 people due to the loss of homes, land and income. ${ }^{12}$

b. people who also have been permanently displaced due to manmade problems, the most prominent one being the construction of dams and reservoirs. For instance, it is estimated that nearly 40 to 80 million people worldwide have been displaced by the construction of dams with many not being adequately resettled.

c. and finally, environmental refugees also include people permanently displaced due to environmental degradation. This is a global issue complicated by the fact that people who are affected by environmental degradation are both the

${ }^{11}$ El Hinnawi Essam, Environmental Refugees, Nairobi: UNEP (1985).

12 The WHO Conference on The Health Aspects of The Tsunami Disaster in Asia, Assessing Needs And Measuring Impact, Assessing Tsunami Related Mortality in Aceh Province, available at http://www.who.int/hac/events/ tsunamiconf/ presentations/ 2_1_assessing_needs_measuring_impact_doocy_doc.pdf (last visited Aug. 03, 2013). 
victims and perpetrators no matter how much or how little they contributed to environmental degradation. ${ }^{13}$

However, Essam El-Hinnawi did not provide generic criteria distinguishing environmental refugees from other types of migrants, nor did he specify differences between types of environmental refugees. His definition makes no distinction between refugees who flee volcanic eruptions and those who gradually leave their homes as soil quality declines. A large number of people fall under the term 'environmental refugees', therefore critics question the usefulness of the concept. ${ }^{14}$

The idea of 'environmental refugees' has been criticised as 'unhelpful and unsound intellectually, and unnecessary in practical terms'. The critics' main complaints are that:

(1) the term 'environmental' oversimplifies the cause of forced migration; (2) there is no evidence of a large number of people being displaced by environmental disruptions (particularly by desertification and rising sea levels); (3) it is a strategic mistake to use the term 'environmental refugees' because it may 'encourage receiving states to treat [refugees] in the same way as 'economic migrants' to minimise their responsibility to protect and assist them' ${ }^{15}$

Yet these criticisms do not provide sufficient reason for not using the concept. First, the term 'environmental' identifies a particular 'mechanism' of displacement and broadens the category of 'refugees'. Second, the evidence of displacement of people that is being contested by critics reflects their scepticism about the severity

13 Brears Robert,Environmental refugees from the Maldives: Are they protected?(Jul. 26. 2009), available atpapers.ssrn.com/sol3/ papers.cfm?abstract_id=1438822 (last visited April 22, 2013).

${ }^{14}$ Diane C. Bates, Environmental Refugees? Classifying Human Migrations Caused by Environmental Change,23(5) POPULATION AND ENVIRONMENT 465(May 2002).

15 Dr. Camillo Baono, et al., Environmentally Displaced People: Understanding the Linkages Between Environmental Change, Livelihoods and Forced Migration (Nov. 2008),available at http://www.rsc.ox.ac.uk/publications/policybriefings/RSCPB1-Environment.pdf. 
of the situation of the people displaced by environmental disruptions. Given that the number of people being displaced by environmental disruptions is on the rise, now is the time for nation states to revisit their responsibilities towards environmental refugees. Third, the criticism that using the term 'environmental refugees' will lead to the treatment of refugees as economic migrants is unconvincing.

\section{Challenges Faced By Climate Refugees}

The interface between climate change and human rights was recognized for the first time in December 2005, when an alliance of Inuit from Canada and the United States, led by Sheila WattCloutier, filed a petition before the Inter American Commission on Human Rights. ${ }^{16}$ The petition alleged that the human rights of the plaintiffs had been infringed and were being further violated on a large scale due to the failure of the United States to curb its greenhouse gas emissions. In the words of the petition, "The effects of global warming constitute violations of Inuit human rights for which the United States is responsible." This is one of the examples of how environment pollution is affecting communities all over the globe.

The terminology adopted for describing environmentally induced migration is controversial. ${ }^{17}$ To call them refugees seems to convey more accurately that they left their homes involuntarily, for reasons not of their own choice. While it is true that there are substantial differences between environmental refugees and economic refugees or migrants, such differences should not blind us from the fact that there exist certain similarities between different types of refugees. ${ }^{18}$

${ }^{16}$ Martin Wagner \& Donald M. Goldberg, An Inuit Petition To The InterAmerican Commission on Human Rights for Dangerous Impacts of Climate Change, available at http://www.ciel.org/ Publications/ COP10_Handout_EJCIEL.pdf(last visited Jun. 19,2013).

${ }_{17}$ Mahbubul Haque, Human Rights Protection Mechanism and Environmental Refugees, available at http://www.icird.org/2012/files/papers/ Mahbubul\%20Haque.pdf (last visited Aug. 03, 2013).

${ }^{18} \mathrm{Id}$. 
The basis for the critique of the term 'environmental refugees' seems to be centered on the need to adhere to the conception of 'refugees' as put forth by the CSR 1951, which requires that refugees be victims of 'persecution' rather than more recent formulations as put forth by other institutions such as the Organization of African Unity's Convention Governing the Specific Aspects of Refugee Problems in Africa1969 (OAUCGSARPA 1969). ${ }^{19}$

The OAUCGSARPA 1969 does not explicitly cover victims of environmental displacement. It focuses only on those individuals with a "well-founded fear of being persecuted for reasons of race, religion, nationality, membership of a particular social group or political opinion" as given under Article 1A(2) of the CSR 1951.

Some nation states and legal scholars have proposed amending the traditional definition of refugee to include environmental refugees, while some have argued that climate change refugees already fall under the definition because they are a 'particular social group' 20 that suffers a form of persecution. It has been argued that environmental degradation is a kind of persecution, and "being forced to live in poverty on land that without warning could flood or turn into dust [...] Whether deliberately or due to omission, these consequences are the result of economic and political decisions. Still this forcefully displaced people are not included in the United Nations human rights protection mechanism. There are regional human rights protection mechanisms also which have not clearly stated the rights of environmental refugees in their Charter. ${ }^{21}$

There is a fear that such an expansion of the term 'environmental refugees' would change the purpose of the CSR 1951and will dilute the protection given to traditional refugees. There has also been political resistance to expanding the ambit of the CSR 1951because

19 Derek R. Bell, Environmental refugees: What Rights? Which Duties?,10(2)Res PuBLICA135-152 (2004).

${ }^{20}$ Frank Biermann \& Ingrid Boas, Preparing for a Warmer World: Towards a Global Governance System to Protect Climate Refugees 8 (Global Governance, Working Paper No. 33, 2007).

${ }^{21}$ Haque, supra note 17. 
of concerns that it may affect the current institutional capacities of United Nations High Commission for Refugees (UNHCR). As mentioned earlier, UNHCR has refused to extend its mandate to include climate change refugees ${ }^{22}$. The biggest hurdle for climate refugees to be brought within the definition of 'refugee' is the application of Article 33(1) of the Refugee Convention 1951 i.e. the Non-refoulement Principle. The following paragraphs debate this principle in detail.

\section{Non-refoulement Principle}

The concept of non-refoulement has been defined in a number of refugee instruments, both at the international and regional levels. The principle is primarily related to human rights protection, notably in relation to the individual protection against acts of torture, cruel and inhuman punishment. ${ }^{23}$ At the universal level the most important provision in this respect is Article 33(1) of the CSR 1951, which states that, "No Contracting State shall expel or return ('refouler') a refugee in any manner whatsoever to the frontiers of territories where his life or freedom would be threatened on account of his race, religion, nationality, membership of a particular social group or political opinion." This provision constitutes one of the fundamental precepts of the CSR 1951 to which no reservations are permitted. It is also an obligation under the Protocol 1967 by virtue of Article 1(1) of that instrument. Unlike some provisions of the CSR 1951, its application is not dependent on the lawful residence of a refugee in the territory of a contracting state. As to the words "where his life or freedom would be threatened", it appears from the travaux preparatoires that it was not intended to lay down a stricter criterion than the words "well-founded fear of persecution" appearing in the definition of the term refugee in

\footnotetext{
22 Fabrice Renaud, et al., Control, Adapt or Flee: How to Face Environmental Migration, U.N. Univ. - Inst. for Env'tE Human Sec., Inter Sections, No. 5/2007,1-48, (2007), available at http:/ / www.ehs.unu.edu/file/get/3973.

23 Elihu Lauterpacht \& Daniel Bethlehem, Refugee Protection in INTERNATIONAL LAW: UNHCR'S GLOBAL CONSULTATIONS ON INTERNATIONAL PROTECTION 87-164 (Cambridge University Press 2003).
} 
Article 1A(2). The different wording was introduced for another reason, namely to make it clear that the principle of nonrefoulement applies not only in respect of the country of origin but to any country where a person has reason to fear persecution.

At a regional level, the Organization of African Unity Convention Governing the Specific Aspects of Refugee Problems in Africa (OAUCGSARPA, 1969) has afforded significant protection to the refugees. ${ }^{24}$ Refugee crises are common on the African continent; therefore it was essential to have a legal regime which applies to Africa. It is interesting to note that the OAU 1969, unlike many other instruments, explicitly recognizes that particular countries will have to call for help when they are overburdened with refugees, and it imposes a duty on the other states to assist. ${ }^{25}$ The principle of non-refoulement is enshrined in Article 2(3) of this Convention. According to Article 2(3), "No person shall be subjected by a Member State to measures such as rejection at the frontier, return or expulsion, which would compel him to return to or remain in a territory where his life, physical integrity or liberty would be threatened for the reasons set out in Article I, paragraphs1 and 2(of the said Convention)"

In Latin America, the scope of the Cartagena Declaration closely resembles that of the OAUCGSARPA 1969. This Declaration was adopted by a group of experts and representatives from governments at a colloquium held in Cartagena, Colombia, in November 1984. Taking inspiration from the OAUCGSARPA 1969 and the Inter-American Commission on Human Rights, the Cartagena Declaration, "includes among refugees persons who have fled their country because their lives, safety or freedom have been threatened by generalized violence, foreign aggression, internal conflicts, massive violation of human rights or other circumstances which have seriously disturbed public order" in

\footnotetext{
${ }^{24}$ Organisation of African Unity, Convention Governing the Specific Aspects of Refugee Problems in Africa, Sept. 10, 1969, 1001 U.N.T.S. 45, available at http:/ /www.refworld.org/docid/3ae6b36018.html (last visited Jul. 24, 2013).

${ }_{25}$ Paul Kuruk, Asylum and the Non-Refoulement of Refugees: The Case of the Missing Shipload of Liberian Refugees, 35 STAN.J.INT'L L.313, 332(1999).
} 
addition to containing the elements of the CSR 1951 and the 1967 Protocol to the said Convention. Although the Cartagena Declaration itself is not a binding legal instrument, it has repeatedly been endorsed by the Organization of American States (OAS). The Cartagena Declaration has widely been accepted as the basis for refugee protection in Latin America and it has been incorporated into the national legislation of several Latin American states.

In the Resolution on Asylum to Persons in Danger of Persecution, adopted by the Committee of Ministers of the Council of Europe on June 29, 196726, it was recommended that the member governments should be guided by the following principles:

"1. They should act in a particularly liberal and humanitarian spirit in relation to persons who seek asylum on their territory.

2. They should, in the same spirit, ensure that no one shall be subjected to refusal of admission at the frontier, rejection, expulsion or any other measure which would have the result of compelling him to return to, or remain in, a territory where he would be in danger of persecution for reasons of race, religion, nationality, membership of a particular social group or political opinion."

In addition to the statements in the above mentioned international instruments, the principle of non-refoulement has also found expression in the constitutional and legal framework of different countries.

The need to provide protection to persons fleeing from their countries due to armed conflicts and civil strife, though they fall within the ambit of the Convention relating to the Status of Refugees, 1951 is generally a state accepted practice based on humanitarian responsibility."27

${ }^{26}$ Asylum to Persons in Danger of Persecution, Committee of Ministers of the Council of Europe, Resolution 14 (Jun. 29, 1967).

27 United Nations High Commissioners for Refugees, UNHCR Note on the Principle of Non-Refoulement Nov.1997) http://www.unhcr.org/refworld/ docid/438c6d972.html. 
The principle of non-refoulement is considered to be the cornerstone of international refugee law. The principle emanates from the right to seek and to enjoy asylum from persecution in other countries, as set forth in Article 14 of the Universal Declaration of Human Rights, 1948.The principle reflects the commitment of the international community to ensure to all persons enjoyment of human rights, including the right to life, to freedom from torture or cruel, inhuman or degrading treatment or punishment, and liberty and security of person. The above mentioned rights are threatened when a refugee is forced to return to persecution or danger. ${ }^{28}$

However, protection institutionalized under international law for the protection of asylum seekers and refugees is not absolute. An example for the same may be acts of exclusion. The exclusion clause in the CSR1951 negates the protection of people who may in fact satisfy the criteria of refugee status. ${ }^{29}$

Further with regard to content, the framework of the CSR1951 is too restrictive to embrace the essential components of the climate change refugee instrument. For example, the CSR1951 places extensive responsibility on the host state, but it does not elaborate on the obligations of the home state. It implies some burden sharing with its mention of international cooperation, but it does not assign responsibility for assistance according to the principle of common but differentiated responsibility.

\section{The Climate Change Regime}

The international framework for climate change is the United Nations Framework Convention on Climate Change, 1992 (UNFCCC 1992) which has a broad mandate for tackling issues related to climate change. The instrument is ratified by 192 state parties. In particular, the UNFCCC 1992 under Art. 8 establishes a

\section{$28 I d$.}

29 Sigit Riyanto, The Refoulement Principle and Its Relevance the International Law System, available at http://papers.ssrn.com/ sol3/ papers.cfm? abstract_id=2211817 (last visited Aug. 03, 2013). 
body of scientific experts and a funding mechanism under Art. 11, and divides responsibilities according to common but differentiated responsibility under Art.4(1).

Despite these advantages, this option has three significant shortcomings:

a. the limits of the UNFCCC 1992's mandate does not focus on remedies;

b. the historical reluctance to incorporate human rights issues explicitly into environmental treaties;

c. the UNFCCC 1992's track record of inaction.

First, the UNFCCC 1992 focuses on preventive measures that protect the environment, not on remedial measures that protect people. The UNFCCC 1992 makes its mandate clear in its statement about its core objective,

The ultimate objective of this Convention and any related legal instruments that the conference of the parties may adopt is to achieve, in accordance with the relevant provisions of the said Convention, stabilization of greenhouse gas concentrations in the atmosphere at a level that would prevent dangerous anthropogenic interference with the climate system. Such a level should be achieved within a time frame sufficient to allow ecosystems to adapt naturally to climate change, to ensure that food production is not threatened and to enable economic development to proceed in a sustainable manner. ${ }^{30}$

Arts. 4, 5, 6, and 9 of the UNFCCC 1992 lay down preventive initiatives, such as the transfer of technologies to prevent emissions, plans to mitigate climate change by addressing emissions, promoting research, scientific studies, education, training, and awareness programs about climate change. The only semblance of a remedial measure in the UNFCCC 1992 is its reference in Art. 4 to adaptation, which does not currently focus on

30 U.N. Framework Convention on Climate Change, art. 2, May 9, 1992, S. TREATY Doc. No. 102-38, 1771 U.N.T.S. 107. 
transboundary refugee problems. Nowhere in the UNFCCC 1992 or the more recent Bali Action Plan of December $2007{ }^{31}$ do the words migrant, migration, refugee, or displacement appear, despite the identification of small island states and those with low lying coastal areas as particularly vulnerable countries. ${ }^{32}$

Although the UNFCCC 1992 seeks to "protect the climate system for the benefit of present and future generations of humankind," it is not designed to provide human rights protections and humanitarian aid to individuals such as climate change refugees after an environmental disruption. The UNFCCC 1992is considered as an agreement between states to anticipate, prevent or minimize the causes of climate change and to mitigate its adverse effects.Thus no existing international legal or political framework addresses the needs of environmental migrants in a satisfactory way. ${ }^{33}$ However, if environmental degradation due to human influence on the climate generates forced migration, then the question of protection of the rights of the victims will become unavoidable. ${ }^{34}$

Climate refugees could be covered under the term internally displaced persons' (IDPs). But it is not a legal term with legal implications. Further, the protection needs of IDPs are not clearly addressed under international law. ${ }^{35}$ In the 1998 Guiding Principles

31 U.N.F.C.C. Rep. of the Conference of Parties on its Thirteenth Session, Dec. 3, 2007-Dec. 15 2007, FCCC/CP/2007/6/ADD.1, 2008.

32 United Nations Framework Convention on Climate Change, preamble, I 19, art. 4(8)(a)-(b), May 9, 1992, S. TREATY Doc. No. 102-38, 1771 U.N.T.S. 107.

33 Benoit Mayer,Environmental Refugees? A Critical Perspective on the Normative Discourse, available athttp://papers.ssrn.com/sol3/ papers.cfm?abstract_id=2111825 (last visited Aug. 03, 2013).

34 Etienne Piguet, Climate Change and Forced Migration, available at http://www.reliefweb.int/sites/reliefweb.int/files/resources/2F0E9CC7 DB1B8F37C125741700516798-UNHCR_Jan2008.pdf (last visited Aug. 03, 2013).

35 Robert Brears, Environmental Refugees from the Maldives: Are They Protected?, available at papers.ssrn.com/sol3/ papers.cfm?abstract_id=1438822 (last visited Aug. 03, 2013). 
on Internal Displacement formulated by the UN Secretary General's Special Representative on Internally Displaced Persons, these guiding principles were drawn from relevant parts of international human rights law, international refugee law and international humanitarian law. ${ }^{36}$

Displaced Persons according to the Guiding Principles on Internal Displacement are, "[...] persons or groups who have been forced or obliged to flee or to leave their homes or places of habitual residence in particular as a result of or in order to avoid the effects of armed conflict, situations of generalised violence, violations of human rights or natural or human made disasters, and who have not crossed an internationally recognised state border." 37

Under international law the rights of those who are internationally displaced as a result of natural disasters, environmental hazards, climate change or other potentially life threatening events are less developed as compared to those who are internally displaced. ${ }^{38}$ Today, no legal instrument under international law defines or offers direct, clear and relevant protection to all environmental refugees. Specialized texts pertaining to foreigners and refugees are generally disappointing and are not sufficient to cater to the protection of environmental refugees. The Geneva Convention 1949 is unsuitable, the OAUCGSARPA 1969 falls short of expectations and there are weaknesses in European Union (EU) instruments relating to asylum and immigration etc. The same applies to texts on international human rights law also. ${ }^{39}$

At the same time, there are limits to host countries' capacity, let alone willingness, to take in outsiders. Immigrant aliens present

36 Vikram Kolmannskog, Future Floods of Refugees, A Comment of Climate Change, Conflict and Forced Migration(Apr., 2008), available at www.nrc.no/arch/_img/9268480.pdf.

37 U.N., Economic and Social Council, Further Promotion And Encouragement of Human Rights and Fundamental Freedoms, Including the Question of theProgramme and Methods of Work of the Commission 12 , E/CN.4/1998/53/Add.2 (Feb. 11, 1998).

38 Martin,supra note 5.

39 Cournil, supra note 4 . 
abundant scope for popular resentment, however unjust this reaction may be. In the wake of perceived threats to social cohesion and national identity, refugees can become an excuse for outbreaks of ethnic tension and civil disorder, even political upheaval. ${ }^{40}$ This is already the case in those developed countries where immigrant aliens are unwelcome, as with the experience of Haitians in the United States and that of North Africans in Europe. Almost one third of developed countries are taking steps to further restrict immigrant flows from developing countries. The measures to uplift the refugees from their plight have also drastically diminished in relation to the growing scale of the problem. ${ }^{41}$ The world's refugee burden is borne primarily by the poorest sectors of the global community. 42

\section{Measures Taken by the States for the Protection of Environmental Refugees: An Analysis}

Some of the countries have taken individual measures for ensuring the protection of environmental refugees:

United States-In 1990, the United States established a Temporary Protected Status (TPS) for those who do not meet the legal definition of refugees, but who still need protection because of the risks they would incur if they returned to their own country. The specific feature of this temporary protection is that it may be granted if there was a serious environmental disaster resulting in disruption to living conditions. The affected state must be unable to cope with the return of its own nationals, and must therefore be designated a disaster area. Temporary protection may last for 6 to 18 months and may be extended if living conditions do not improve in the affected country. TPS only applies to persons already resident in the United States at the time of the incident and only when a formal request for protection has been made by the state of origin. Applications have included those made by Nicaraguans and Hondurans after Hurricane Mitch in 1998, and by

40 Norman Mayers, Environment Refugees: A growing phenomenon of $21^{\text {st }}$ century, 357 (1420) PHIL. TRANS. R. SOC. LOND. B, 609-613 (Apr. 29, 2002).

41 Id.

42 Id. at 611. 
migrants in the wake of volcanic eruptions. ${ }^{43}$ The possibility of granting TPS to Haitians is currently being discussed. As it stands, this protection regime is still very ad hoc and is insufficient to cope with the expected migration scenarios.

New legislation in the Nordic countries should also be examined with a view to harmonizing regional cooperation on environmental refugees.

Denmark- Denmark has granted protection to unmarried women and families with young children in geographical areas where living conditions are regarded as extremely difficult owing to famine or drought. In the proposition for a new Aliens Act in Norway, the Ministry of Immigration has recognized the need to grant residence permits to applicants who come from a region affected by a humanitarian catastrophe, including a natural disaster.

The international community cannot ignore environmental refugees owing to the lack of an institutional mechanism to deal with them. The experience of the UN Convention on the Rights of All Migrant Workers and Members of their Families 1990 whose modest innovation consisted mainly in stating that irregular migrants should enjoy universal rights too, shows the limited capacity of developing states to impose international norms. Twenty one years after its adoption, the Convention has been ratified by only forty three states, mostly Latin American or Western African countries. None of the developed countries have ratified this Convention. This certainly shows that, while the global north can successfully pressurise developing states to ratify and implement human rights conventions sponsored by it, a human rights agenda only supported by developing states is unlikely to have a great influence on northern countries, nor even on reluctant southern countries. ${ }^{44} \mathrm{On}$ the other hand, developing countries

43 Jane McAdam, Environmental Migration Governance, (Faculty of Law Research Series 2009, Working Paper No. 1), available athttp://law.bepress.com/unswwps-flrps09/art1 (last visited Aug. 09, 2013).

44 Mayers, supra note 40 at 610. 
devote only $10 \%$ of their development expenditures to priority human needs, such as water, sanitation, nutrition and health, the lack of which is often a contributory factor to the environmental refugee problem. ${ }^{45}$

The expansion of existing multilateral treaties such as the CSR 1951 or even the UNFCCC 1992 to incorporate protection mechanisms for those displaced due to environmental change may not necessarily be the answer to tackle the problem of displacement linked to the environment. There is already a saturation being experienced with the ratification of multilateral treaties. ${ }^{46} \mathrm{It}$ is quite unlikely that in this age where most states are endorsing extremely restrictive immigration regimes, there would hardly be any willingness to undertake further obligations. Hence, the need of the hour is a separate convention for climate refugees.

\section{Conclusion}

The issue of environmental refugees is one of the foremost human crises of the present times. However, climate change induced migration is certainly a sufficient reason for a new international organization to be established. A new legal instrument carefully crafted to deal with the problem of climate change refugees is the best way forward. It should guarantee humanitarian aid for those who are compelled to leave their countries due to climate change. The responsibility of providing such assistance has to be shared by the international community. The nation states have to respond proactively to the cause of recognising and protecting the environmental refugees and have to reach a consensus with respect to the same.

45 Mayers, supra note 40 at 612.

46 Bhat, supra note at 8. 